University for Business and Technology in Kosovo

UBT Knowledge Center

UBT International Conference

2013 UBT International Conference

Nov 2nd, 12:15 PM - 12:30 PM

\title{
Urban Land Management Policy For The Central And Local government In Albania
}

\author{
Gjergi Thomai \\ Albanian University, gjergjthomai@yahoo.com \\ Daniel Guralumi \\ Albanian University, guralumi@wind.it \\ Iva Mezezi \\ Albanian University, imezezi@yahoo.com
}

Follow this and additional works at: https://knowledgecenter.ubt-uni.net/conference

Part of the Architecture Commons

\section{Recommended Citation}

Thomai, Gjergi; Guralumi, Daniel; and Mezezi, Iva, "Urban Land Management Policy For The Central And Local government In Albania" (2013). UBT International Conference. 13.

https://knowledgecenter.ubt-uni.net/conference/2013/all-events/13

This Event is brought to you for free and open access by the Publication and Journals at UBT Knowledge Center. It has been accepted for inclusion in UBT International Conference by an authorized administrator of UBT Knowledge Center. For more information, please contact knowledge.center@ubt-uni.net. 


\title{
Urban Land Management Policy For The Central And Localgovernment In Albania
}

\author{
Gjergj THOMAI ${ }^{1}$, Daniel GURALUMI ${ }^{2}$, Iva MEZEZI \\ 1,2,3 Albanian University, \\ Tirana Albania, \\ gjergjthomai@yahoo.com, guralumi@wind.it, imezezi@yahoo.com
}

\begin{abstract}
The peculiar character of urban land influences the urban land market: (i) Land is physically undepreciable and is not influenced by time. (ii) Land is not transportable, (iii) Land is limited in quantity and its supply cannot be increased, and (iv) Land is used not only for production purposes but also as a long-term investment or as a bas is for savings. Urban land management is a complex and highly dynamic situation that requires:

- $\quad$ knowledge and understanding of the dynamics and processes of urban growth in a segmented and unregulated land driven market;

- $\quad$ capacity to formulate strategic approaches to planning and development; and

- legislative authority to implement proactive initiatives.
\end{abstract}

Now day's respective public institutions are not well positioned to address the broader is sues and strategies of urban development, yet their decisions create legal precedent and produce concrete activities, which affect the urban environment.Procedures and planning normative are ineffective and inefficient, standards need to be studied and the most important one the land ownership needs to be clarified.Demographic growth, rural urban migration, the rapid expansion of the urbanized zone, land ownership changes, and change in demand and supply of the land resulted in chaotic development patterns, wasteful of land resources and costly to provide with infrastructure and urban services. With the land transactions and building activity occurring outside the legal framework for development, documenting ownership, registering titles, and recording transaction are becoming extremely complex, that in a way are obstacle the intervention for later improvement. The challenge faced by the government is to introduce a comprehensive land management with a mix of options. The purpose of this paper is to review and assess the central and local government policy on land management and development. At the same time, it will also identify the main problems, strengths as well as weaknesses and the area that needs to be improved.

Keywor ds : urban, land, management, regularization, market.

\section{Introduction}

Albania a small country in the East-South Europe, with about 3.2 million inhabitants on its area of 29.000 square km, was basically on agriculture based economy with a low industrial-technological development. Based on the socialismprinciples, the country is highly centralized, and for 50 years, it developed in such a way that it separated itself fromother countries without communication, cooperation and collaboration which resulted to low-productivity and-efficiency and low economic growth. Private properties and initiatives did not exist. Land was the property of the state. Development was projected, financed and implemented from the central government. The land management (administration and use of the land) was the task of the state and the system was functioning in a hierarchic direction from up to bottom. Planners were free to decide on the land use (based on the agriculture land preservation principle)

After year 1990, economic opportunities emerged in the cities. Demand for land (especially serviced urban land) changed as a result of the following major factors:

- Recent economic and political changes in Albania; 
- The combination of cramped housing conditions and individual hous ehold investment strategies that view housing as both shelter and financial security; and

- The rapid growth of the population in Tirana and Durres areas.

Consequently rural-urban migration ratio quickly has been changed. In this framework, the population of the Tirana-Durres Area has been growing at the alarming rate up to 7 per cent per annum since 1990 (especially Tirana City). Tirana-Durres area population is estimated more than 850000 inhabitants; more than $60 \%$ are living in urban areas. The built environment of Tirana now occupies more than 2.500 hectares as compared to the 1.600 hectares in 1990 . The vast majority of this development has been constructed by the informal sector. The growth has occurred around the city and has expanded over the municipal boundaries. The newly urbanized areas, lacking basic infrastructure, are generally being constructed without any permits and often without title to the land. The government was not prepared and did not react to improve the situation; agencies responsible for the provision of basic infrastructure have not been prepared to respond to this sudden growth. The passive policy of the state during this time created many problems and private activities created many externalities that both of them need to be solved.

\section{The Urban Land Market And Its Peculiar Nature}

The forces of supply and demand govern urban land market, like any other market. These forces determine the dynamics of urban land market operations and thus affect adjustments to land prices. Unlike other markets, however, land is not a homogenous product. Each plot is unique, with a particular set of location and physical attributes, and actors in the urban land market are diverse and often have conflicting agendas. (Farvacque and McAuslan, 1991).11

An urban land market is a set of activities, which, through exchange of value, transfers rights (formal or informal). Urban land is supplied by different actors, and is demanded by others; matching supply and demands results in prices. An efficient urban land market has a good interplay between demand and supply. The demand for land is determined by the product or service produced on the land, in other words, by the use of the land. This characteristic, in itself represents a fundamental difference between land and other commodities. Demand is affected by demographic and economic pressures such as rate of household's formation, the level of household's income, the capacity of mobilizing household savings and access to credit. (Farvacque and McAuslan, 1991). On the supply side, the quantity and price of land are affected by the spatial pattern of infrastructure (the constraints on infrastructure capacity frequently impede land development): the topography, which determines the extent to which the land can be developed physically: the willingness of land owners to make urban land available on the market; and by the government's restrictions on the use of land. (Farvacque and McAuslan, 1991). Land prices in the market, as the other goods, are influenced by many factors. One set of factors concern the changes in the urban economy and society itself, and another set relates to macro-economic factors, principally economic growth and its side effects. An understanding how these factors are interrelated and the role each plays in determining land prices are important to understanding the functioning of the urban land market. As the basis for a land value is its accessibility (which includes the effects of transportation and the distance to city functions that means land location), environmental features (which includes both the social and physical environment). (Darin-Drabkin, 1977). 12

The peculiar character of urban land influences the urban land market. That is, the general law of supply and demand does not influence the urban land market in the same way as it does other commodities. The demand for and the supply of land are always related to the characteristics of specific locations, dependent from the land use, as well. Some of the unique qualities, which distinguish it from other goods, are:

- $\quad$-Land is physically undepreciable and is not influenced by time. Here should be distinguished raw land from built land. The structures built on land are depreciable, but the land on which this development occurs is undepreciable. The depreciation of a structure sometimes may increase the value of the land because of an expected change in use, and fromhere, an expected change in income generated by land. (Doebele, 1978). 13 
- $\quad$-Land is not transportable. It means that the forces of demand and supply in certain areas fix the price of land, not by the availability and demand in the entire city, region or country. Thus, it is hardly possible to talk of a national market for land in the same way for different goods. (Darin-Drabkin, 1997). 14

- $\quad$-Land is limited in quantity and its supply cannot be increased. These unique characteristic of urban land, the fact that the amount of land in the desired place is inherently limited, and the fact that land cannot be used for production purposes with relatively little penalty (taxes), may lead to a permanent disequilibrium in the land market between supply and demand. However, the intensity of land use may be increased. (Darin-Drabkin, 1997).

- Land is used not only for production purposes but also as a long-terminvestment or as a bas is for savings. As demand for land increases, its price rises, but paradoxically, this higher demand does not necessarily always increase the supply, but may reduce it as the landowners expect future development and higher profit from their land. The scarcity of land and the physically undepreciable character of land make it profitable. (Darin-Drabkin, 1997).

\section{The Functioning of The Urban Land Market And The Role Of The Government}

Unlike other markets however, ease of entry or exit is closely controlled by local and national government policies. Well-functioning urban land market can therefore be characterized by the level of ease of entry into the system and of carrying out land markets transactions, both of which depend on the availability of adequate land information, secure tenure arrangements, and appropriate registration/recording mechanism. On the other hand, non-performing urban land markets are plagued with a number of problems easily recognizable and commonly found such as (a) over centralization of management and administration; (b) inappropriate, over detailed, and inflexible regulatory and legal frameworks; (c) lack or inappropriate use of resources and political will to tackle the problems; (d) administrative systems lacking in efficiency, equity, accountability, and probity; (e) a failure or reluctance to encourage participation from the urban poor.(Farvacque and McAuslan, 1991).

The price of land will increase not only in an expected area, which will be affected by developments, but will increase the land price over an area, which is not developed. Therefore, will affect negatively the public budget for the future public investments. (the compensation cost for expropriation purposes will increase). Because the landowner behavior s produce the same results as a monopoly, higher prices and reduced supply, the role of public authorities, their policies and instruments apply to land market become crucial. (Darin-Drabkin, 1977)

According to Dowall and Clarke (1991), 15 there are three justifications for the government involvement in the urban land market.

- -Elimination of market imperfections and failures to increase operating efficiencies.

- $\quad$-Remove the externalities, based on the its intervention by laws, regulations and norms so that the social cost of land market outcomes correspond more closely to private costs.

- $\quad$-Redistribute society's scarce resources so that disadvantaged groups can share in society's output (Moore 1978)

The institutions and instruments which between them provide for the management and operation of urban land markets should be based on the principles of equity, efficiency, flexibility, and participation with the overall aim of facilitating increased access by all citizens, and especially the urban poor, to affordable and appropriately located land with adequate security of title and occupation and adequate development rights (Farvacque, McAuslan 1991)

According to Dowall, (1991), there are many points that can impede goals of achieving efficiency and equity allocation of land.

- $\quad$-shortage in public financial resources for all types of investments, related to annual output per capita, and to high inflation. 
- -externalities generates by the design standards, which hamper the ability of most target people to pay.

- -weak capital market, due to the economic features.

To remove these constraints it is necessary to identify where distortions are occurring, and where the policies and regulations that contributes to distortions. Beside that it is necessarily to improve the institutions and instruments due to the land issues, to support the effective operations of urban land market, and to improve governance of land, such as institutional, technical, cultural, financial, environmental, and political forces affect decisions making in urban land market and land management.

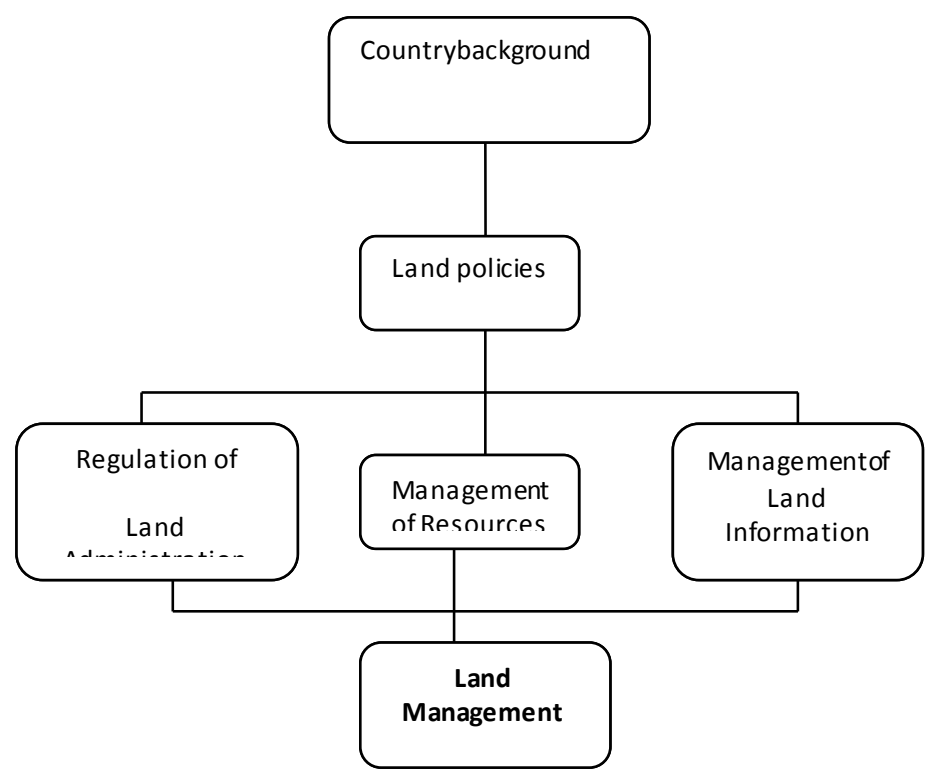

Fig. 1: Regularization of Land Management

\section{Existing-Main Problems}

At the given situation the main common problems faced by the government and cities are:

- Lack of strategic plan for development and its non implementation, lack of territory planning strategy regarding the balance of land use (urban, rural,) where the development will be spread out;

- Lack of land supply, especially serviced land;

- High cost of existing and available urban land;

- High cost of construction;

- Increased of unemployment;

- Delay in restitution and compensation of the land to the ex-owners;

- Inability of the public and private sector to service land;

- Shift of the responsibilities from the central government agencies to the local government agencies (not clear responsibilities);

- Lack of planned intervention for the development;

- Lack of financial resources;

- Uncertain planning and norms adequate to the situation;

- Lack of skill and capacity;

- Improving financial structure and management;

- Providing shelter, basic urban services and infrastructure; 
- Improving urban information systems;

- Strengthening the role of the urban informal sector

- Strengthening urban institutional capacities, including the ro le of municipal governments;

- Increasing the ability of the government to coordinate the delivery of trunk and secondary infrastructure among its agencies and local authorities.

Based on the problems emerged in the cities the government supported by foreig $n$ aid introduced basic approaches in order to improve that situation.

\section{- $\quad$ Site and Services approach}

Stressing on the situation and the problems, The Ministry of Public Works, the National Planning Institute, the District of Tirana and the Municipality of Tirana have been working together on formulating strategies for meeting the demand for serviced land. A Land Management Task Force (LMTF) has been established to formulate these strategies with foreign technical assistance. Critical areas requiring attention include:

- Planning and prioritizing land development;

- Trunk urban infrastructure development, especially access infrastructure, such as water supply, sewerage, and roads;

- Municipal, land, and infrastructure finance;

- Institutional coordination and capacity building associated with the delivery of serviced land and trunk infrastructure, and

- Legislative reform to remove bottlenecks in the delivery and finance of the infrastructure for urban land.

As means of identifying practical strategies, the LMTF has initiated the development a pilot site with full cost recovery from the purchasers for the land and infrastructure. The site was vacant and the government still holds the title of the land. The strategy identified for the development of the site was the involvement of selling parcels of land to the private sector, including larger developers, small and medium contractors, and individuals. Private developers were responsible for the construction of the on-site infrastructure, and a Project Implementation Unit for the off-site one. The project failed as a result of:

- The government was not able to receive the full value of the land, which would allow them to provide infrastructure on a cost-recovery basis;

- There were no clearly defined institution or coordination of the activities of several institutions to oversee the selling and servicing of the land;

- There was no coordination and integration of the implementation of both the off-site and onsite infrastructure among the institutions involved in its delivery;

- As a result the project was delayed and the land (high demand for land and housing, and migration) was invaded.

But the vast majority of housing is being provided by the informal sector in Greater Tirana and is being built by the small-scale builders and the individual owners. Illegal settlements are characterized by land ownership and occupancy rights that cannot be easily substantiated and by planning approvals and buildings permits that have not been obtained (although residents have obtained connections to public utilities). Site chosen include areas that lack access to infrastructure -low land prices. As mentioned above these areas are not environmentally and healthy assured and they create problems to the whole city.

The problems with the site and services approach were:

- The cost of the project was high making houses no longer affordable;

- People did not take part in the project (although the project did not start at the time as a matter of affordability too);

- Special agencies were created to run the site and services projects but still it created other problems and delayed the project (not a complete structure of the new agencies); 
- The level of projected infrastructure was too high stimulating people and private sector to stay far from the project;

- The project was not seen as a policy to solve the problem and did not take into consideration the characteristics of the country, mentality of the people, political support, and institutional capability.

- Neighborhood Improvement and Infrastructure Upgrading Program approach

After the Site and Services approach failure, the Ministry of Public Works, in cooperation with the Municipality of Tirana and the District of Tirana developed an infrastructure program to improve services in residential zones.

The Tirana Neighborhood Improvement and Infrastructure-Upgrading Program was based on the desire of residents to improve environmental conditions in their neighborhoods. It also addresses the role central and local government can play in planning, regulating and funding infrastructure improvements and joint-infrastructure investments between residents and local government.

Land Management Task Force was responsible to initiate and develop this program in cooperation with Neighborhood Initiatives Groups within the local government, in order to provide a flexible structure to develop land management strategies and direct capital investments at both Tirana-Metropolitan level and within neighborhoods.

The urban upgrading program seeks to implement an immediate action, in order to upgrade obsolete infrastructure and extent services to under-serviced neighborhoods, informally developed zones and, when appropriate, adjacent vacant land that requires off-site services.

The Residential Upgrading Program was based on a partnership approach that will bring central and local governments together with the residents' priorities and willingness to participate in jointinfrastructure programs. Infrastructure projects for upgrading include secondary on-site, off-site and primary systems that respond to new planning and environmental initiatives prepared by Land Management Task Force. The objectives include:

- Upgrading and extending of primary and secondary infrastructure to service residential zon es, improve the quality of services and guide new patterns of urbanization in Greater Tirana;

- Regularizing informal urban settlements and establishing pragmatic and workable controls over the land development process;

- Coordinating and rationalizing inter-governmental transfers for infrastructure investments, including cost sharing principles between local government and residents, and creating the regulatory framework for private sector provision and maintenance of infrastructure;

- Developing a framework for participatory planning, communities outreach and use of community-based organizations and initiatives;

- Institutionalizing a strategy and inter-jurisdictional structure to undertake Land Management and Neighborhood Upgrading projects in Tirana and other cities.

The problems with the Neighborhood Improvement and Infrastructure Upgrading Program approach were:

- It should be based on the legal framework;

- It needs political support, willingness, taking the responsibility at the given situation and political agreement in order to keep the project far from the political campaign;

- It should include planning framework in order to support the project;

- It needs a well fixed strategy on the employment (result of this chaos), income generation in order to make the project implementation easier;

- It should start with community creation groups (desire of the people to improve the situation does not come from the central government from up to bottom approach);

- At the moment the existing bank system is not able to support the credit objectives of the project. It is needed another solution for it;

- Land restitution and compensation; 
- Capability of the local government and its independence from the central government;

- Cooperation with NGO's and CBO's as well.

\section{Legalization-urbanization approach}

The major initiative to address the problem of illegal settlements has been the adoption of Law "On Legalization and Urban Planning of Informal Zones". This law provides the procedure by which the informally settled areas can be re-designated as urban zones, thus allowing the persons who have constructed housing and other trade and service buildings to legalize them. The law, therefore, envisions a procedure with three parallel elements:

- re-planning of the informal zone to insure its proper functioning as an urban district, with necessary infrastructure;

- bringing the existing buildings into compliance with construction and land use standards and legalizing them under the administrative law; and

- settling the rights of the persons occupying the land and buildings so that they achieve compliance with the civil law.

The law outlines a procedure in which municipal and state agencies must take actions, simultaneously with actions of the private parties, in order to bring about all three elements of legalization.

It must be recognized that the law "On Legalization and Urban Planning of Informal Zones" does not deal directly with the problems of inadequate infrastructure and integration of these informal zones into the urban system. It only provides that an urban planning study will be carried out and that, upon its completion, the municipal government will take the necessary actions to remove buildings and structures in the way of public facilities. This is a significant weakness in the process because the obsolete methodologies of urban planning address spatial issues and provide no mechanisms for financial and capital planning related to infrastructure.

No urban planning studies or regularizing studies have been conducted previously. They will be part of the legalization and urbanization process, and consequently, will need ample time to be prepared, which will noticeably make difficult the timely and qualitative implementation of the law.

Meanwhile, the current experience in Albania has repeatedly shown that the timely and correct implementation of laws has been the weakest component of the state administration activity.

What would be the prognosis of the implement ability of this law? This remains a very difficult answer.

\section{Legal, Financial And Institutional Issues}

Legal and Administrative Constraints Impeding the Development of the Functional Land Markets

- Security of Property Rights Through Reforms

It is very important to understand property rights security. For that the most important is the finalization successfully the reforms as mentioned below. At the same time it requires the introduction of new other reforms related to land administration.

- The reforms on the agriculture land to be finalized

- The problems of ownership on the touristic land to be resolved

- Land restitution and compensation process to be finished

- There are too many process on the property conflicts in the courts;

- The registration process to be finished.

- Land Valuation and Sales Prices

In Albania, the emerging land markets suffer from imbalances and dysfunction that tend to segment the market, distort prices, and affect relatives' rates of appreciation. 
The base price designated in the law does not reflect current values. These prices are given only for the land within the municipal boundary, ranged from the periphery to center, from residential zones to commercial ones. Fixed prices failed to reflect the relative advantage of each parcel in terms of location, access, service, size and shape, as well as the desirability of the area from the social and environmental viewpoints.

In Albania, the land became the most rapidly appreciating commodity, driven by the infusion of capital from remittances and local and private savings. Uncontrolled growth patterns led to dramatic changes in land values over very short periods of time as a result of infrastructure projects, remittances, expectations regarding exchange rates, inflation and alternative investment opportunities.

(Note: There are improvements of law on of property evaluation methods but still there is high informality in transaction).

\section{- The Transfer and Disposition of State-Owned Land}

To overcome this constraint, public authorities have resorted to leasing land to developers who undertake the steps to subdivide and valorize the land. Individuals who purchase finished houses can register the property in their own name and pay the fixed price of land to the local authorities. This procedure is highly unsatis factory. It allows to the private developer to collect the high value of serviced land, a public asset they do not own, through the price of the newly built houses. It deprives the public authorities from recovering the real value of their assets. It erodes the capacity of the government to finance infrastructure projects.

- Unregulated Development and Informal Settlements

Approaches to regularization should be based on the following.

- Recognizing the official document establishing property rights pending the registration. These rights are transferable even if properties have to be legally kept under joint/shared ownership rather that subdivided among the holders of various rights. Trans fers of the property rights will continue to be transacted freely on the informal market. The problem is that successive undocumented transaction lead to confused situations that can be further complicated by conflicting claims and restitution.

- Establishing simple and expeditious procedures to record occupancy rights. - Settlers typically access land in one of two ways: they acquire property rights from presumed holders who parcel off the land and sell building plots; or they buy occupancy rights from the previous settlers who subdivide and sell part of their parcels. These unregistered transactions are usually documented between the two parties by a bill of sale, which is sometimes attested to by witnesses and notarized. Registration procedures stipulated in the law on the registration of real estate require holders of undocumented property rights to obtain a notarized declaration from the neighbors and witnesses, supporting the validity of the ownership claim and the occupancy of the boundaries. The process can be cumbers ome, but it also helps defuse conflicts and avoids having the ownership status of land tied in endless litigation. Alternatively, settlers could document their rights by obtaining a certification from local councils verifying their claims. The former procedure is slower; the latter is more politicized. So recommendation to map buildings in informal settlements and record existing buildings without recording the surrounding land greatly diminishes the usefulness of the record. For the land management purposes, the boundaries of the land claimed is more important than the footprint of a building, which may be expanded horizontally as well as vertically

\section{Financial Issues}

\section{- Fiscal Administration}

Last year's there are positive developments regarding this process. But still the capacity of Local Governments regarding the property tax collection is low.

The delegation of local urban public services to the municipal and district level is, very comprehensive. However, it occurs within an administrative framework where local governments have no legal or 
financial autonomy. Local governments are executing programs developed by the central ministries, which formulate and allocate budgetary funding for the services at the local level.

There are a number of taxes collected directly by the local government units, which they are allowed to spend more at their own discretion. These local taxes are used for supplementing centrally funded expenditures. Local financial officials are concerned with the recording and reporting of financial information. What are lacking are the tools for financial analysis and a municipal management system that demands financial planning to guide investment decisions.

\section{- Financial Performance}

A large proportion of local expenditure is directed at social services, rather than infrastructure with education and health services particularly emphasized. These social services are "operational"-driven, rather than "maintenance"-driven. This is reflected in poorly functioning water supply, sewerage, drainage, and solid waste services.

The competition for the available limited funding results in inadequate financial resources for capital investment into both rehabilitation and new facilities to serve the expansion needs of the city.

It is unlikely that these low levels of funding will continue given that the government budget is under pressure because of fiscal deficits. Only a small portion of this deficit represent capital investment that in the best circumstances could justify public borrowing.

\section{Institutional Issues}

The Ministry of Public Works and Transport leads the current organizational structure among central and local government, in the field of urban land management. At the given moment there is a lack of coordination between central and local government priorities and implementation capabilit ies. The costs of infrastructure improvement are high as a result of uncoordinated use of local and outside funding sources. The land use planning is not coordinated with the infrastructure provision.

The majority of new informal settlements and land available for development is located on or in close proximity to the existing municipal/district boundary. To plan and service these areas with infrastructure, cooperation is required among central government, two or more local government jurisdictions, and several sectoral agencies. Additionally, major infrastructure investments and environmentally sensitive projects require coordination on a metropolitan level.

(Note: There are 30000 ha of informal building over the country that creates difficulties in the land management process).

The need to upgrade the housing and infrastructure of the existing urban and fringe areas of Tirana is a critical point to achieve sustainable and equitable development in the city. For high - and middle income groups, the main issue is to provide serviced land and housing and to improve the trunk and immediate access infrastructure. For low-income groups the need to provide infrastructure and serviced land is complicated by the social conditions, cultural perspectives and financial limitations of these groups. Regard to this, there is a need to assess the extent, ability and willingness of these groups to contribute toward their own development. This will involve a community-managed approach to the provision of infrastructure and other services.

\section{Strengths/Weaknesses}

- Presence of laws concerned to land management;

- Increased number of agencies responsible to land management;

- Growing interest about land management;

- Growing number of trained professionals to provide as sis tance of plan prep aration intervention and implementation;

- Increased power and authority to local government in formulation of their plans;

- Increased concern of the community for intervention and upgrading.

- Lack of a national strategy on land administration and information unification; 
- Rules and responsibilities of the institutions responsible are not clearly defined;

- Policies, strategies and objectives are not clearly defined;

- People involved in urban land management lack the technical capabilities and they have negative attitude towards land management;

- Plans are not subjected for consultation and public hearing;

- Participation from the private sector and community is not encouraged;

- Data/information are lacking which leads to non-transparency (and not complete);

- Personnel are not motivated because of lack of incentives for other remuneration;

- There is no close monitoring of programs-projects implementation;

- Inadequate financial support;

- The credibility of the government is already deteriorated;

- Lack the vision of the sustainable development;

- Lack of technically capable professionals;

- Highly centralized plan approval process;

- No vertical and horizontal integration among institutions, agencies and communities;

- No strongly political support.

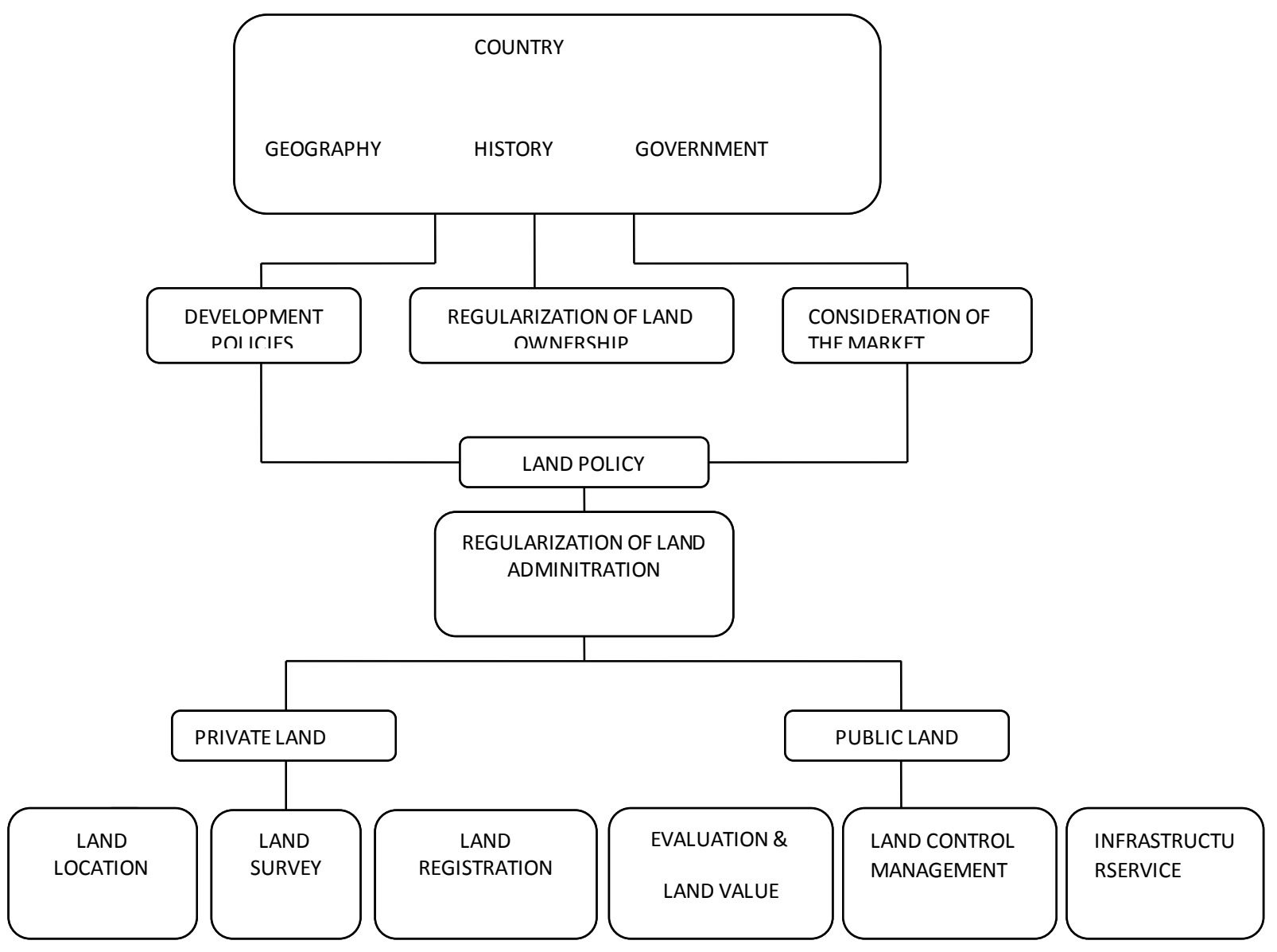

Fig. 2: Regularization of Land Administration

\section{Areas For Further Improvement}

\section{Legal Area}

One of the most important areas for improvement is the legal one. 
- Transparent procedures of public participation on decision-making process;

- Continue the work of setting criteria and qualifications for licensing of real estate appraisers;

- Improving procedures for registration and licensing have certified appraisers;

- Compiling an atlas of appraised land values in different sectors of Tirana as a first step in the creation of a database for land management;

- Computerizing and linking cadastral maps, ownership records, and assessed valuations;

- Sell serviced land and un-serviced land by public auction;

- Negotiate with the potential developers and investors of larger projects to seek the most advantageous package from the viewpoint of the public sector;

- Improvement of regularization procedures in order to avoid embroiling urban planning and management agencies in legal issues of property rights and tenure;

- Improving registration procedures in defining the boundaries of the land plot claimed by each settler and their characteristics.

\section{Financial Area}

There will be little funding available from local sources in order to support development of land, given the tremendous needs for it. Selling serviced and un-serviced land is promising source in supporting development. The present administrative framework limits the opportunity to generate funds from the sale of serviced and un-serviced land. To undertake this process, there are steps that should be taken:

- Strengthen the capability of local government to plan, budget and implement programs;

- Develop a system of property tax;

- Restructure regulations, which not allow the sale of land;

- Allow the local government to raise profits fromthe land sale that should be channeled into offsite access infrastructure-use of the benefits from tax collection clearly and for the same direction.

\section{Institutional Area}

At the given situation, under an integral approach, localgovernments should establish priorities with central government and non-governmental (NGO) and community based organizations (CBO) in order to identify needs and priorities by area and sector, investments, operation and funding plans, options for public and private sector participation. A structure can be established that:

- Empower of land administration structures (i) organization of cadastres of urban land, agriculture land, forest, etc; (ii) establishment of fiscal cadastre (iii) empowerment of legal cadastre (registration system);

- Encourages planning, programming, and identification of investment priorities by all levels of government through a decentralized and integrated approach;

- Strengthens local government's capability for resource mobilization for urban infrastructure;

- Strengthens the institutional capability to local government to plan, budget, and implement programs. This will require training staff and technical guidance;

- Coordinate development services, activities and investments affecting local government jurisdiction;

- Develop policies and strategies for land management;

- Providing assistance in identifying and resolving legal, financial and administrative impediments to the achievement of its objectives;

- Encourage relations with NGO's and CBO's as they play a strong role in the activities with lowincome groups and as intermediator between public authorities and residents;

- Using CBO's and adopting a participatory approach;

- Focusing on building self-help approach among target groups;

- Operating small credit schemes for employment generation and home improvement;

- Acceptance and understanding in government agencies of the important role NGO's play in the development process, allowance of the government to contract NGO's to perform development and upgrading work. 


\section{Conclusions}

Legal System

"A good law being one that guarantees and facilitates the efficiency of the economic and socialactivities it regulates and a bad law, one that disrupts or totally prevents it" (de Soto 1989):

- The published laws are deficient in a number of respects; from the form they are published, to the way in which they define the fundamental nature of the power relationship between the state and its citizens. The laws many times are not published at all and they are not available to the public. Many laws are published in a language not familiar to the citizens;

- Draft and publish land laws in forms that will make them easily available to the public;

- It should be created or revive specialized mechanisms for land involving formal courts, traditional and local community mechanisms;

- Training of professionals to lead the system and to fulfill this task;

- Law on Land Administration including (i) unify the information for land (ii) land value (iii) land use and other attributes.

- Institutional System

Decentralization of the land registration, allocation of the publicly controlled land and all permits and approval needed to undertake development of land via a "one-stop shop".

- Shift of the responsibilities from central government to local government and local communities or traditional bodies to undertake local land management tasks;

- Develop transparent, simple and fair administrative processes and procedures to handle land issues and to involve private sector actors in the process;

- Train local officials and private actors to undertake tasks in the administrative environment;

- Develop incentive-based systems of personnel management in relation to public agencies concerned with land management;

- Establish a monitoring mechanism (public-private) to keep under review the operation of the decentralized system of land management and to further the progressive involvement of private sector professionals and NGO's in land management tasks;

- Reorganization of the institution responsible for land management based on policy and law of land administration.

- The government should operate and support these strategies and land development through land policies:

- Policies to affect ownership----where government affect the market through pricing, expropriation etc in order to make land available for itself or for the lower-income groups;

- Policies to affect land prices----where government intervenes through firstly taxation, land banking, regulation of building, secondly increase of land supply through servicing land and thirdly through vacant land taxes;

- Policies to affect use----where government intervenes through firstly land use regulations and secondly through investment in facilities;

- Policies to obtain revenues----where government intervenes through taxation and sale of the land.

The reform of urban land policies should be introduced in:

- Land Market Assessment of the operation of the land market (prices, supply, new projects) in order to assure the all data of land transaction and reduce informality;

- Decentralize Land Management Authority;

- Deregulate (simplifies control, approval and match demand with supply);

- Curtail Public Land Development Agencies (performance assessments);

- Improve Efficiency of Land Market Operations (title registration, transaction, and cadastre);

- Provide the Financial, Institutional and Spatial Structure for Installing Infrastructure Networks. 
Application of the recommendations above mentioned and reforming urban policies will strongly depend on the political willingness and central and local government commitment.

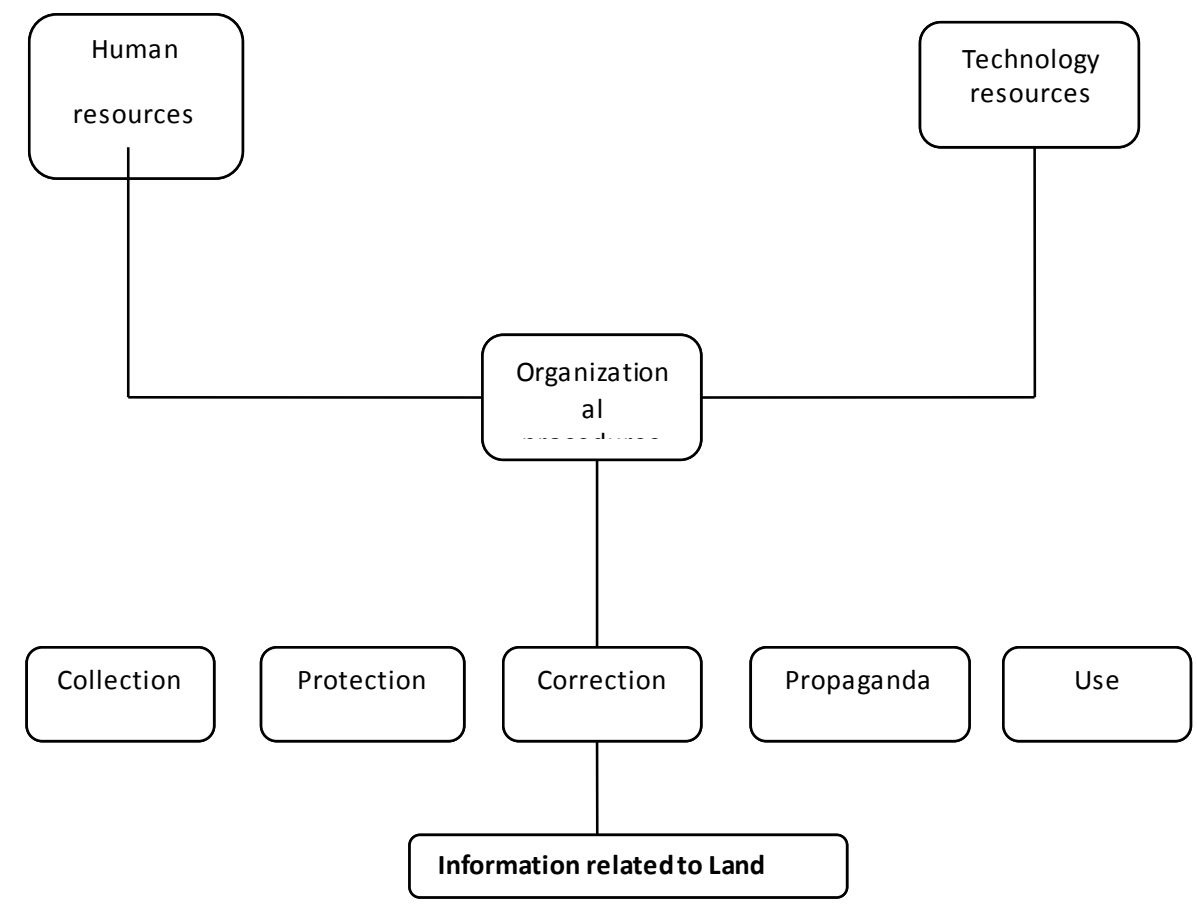

Fig 3: Land information systems

\section{References}

1. Land Management Task Force, Land Development Pilot Project in Western Tirana, 1995;

2. Land Management Task Force, Tirana Land Management Program, 1995;

3. Land Management Task Force, Tirana Neighborhood Improvement and Infrastructure Upgrading Program, 1996;

4. Albanian Gov't, Collection of Albanian Laws, 1992-1997;

5. M.P. van Dijk, Employment in World Bank Urban Development Projects in Africa, 1990;

6. M.P. van Dijk, Changing perspectives on urban law income housing in developing countries, an incident in a slum improvement project, 1997;

7. Farvacque. C, McAuslan. P, Reforming Urban Land Policies and Institutions in Developing Countries, 1991;

8. Nientied. P, Aliaj.B, Managing Tirana's Rapid Growth (Outcomes of the Workshop and Executive Seminar), 1997;

9. Nientied. P, The Question of Town and Regional Planning in Albania, 1997;

10. Maas. B, Nientied. P, Municipal Property Management in Transitional Economies: The Case of Bratis lava, Slovak Republic. IHS Rotterdam, 1996;

11. IHS Rotterdam, Szczecin, The Management of Municipal Real Estates: (the typology, use, review, development, maintenance and disposal of local authority property), 1997;

12. IHS Rotterdam, Szczecin, Banking on Cities: (the use of municipal as sets for urban development finance), 1997; 
13. UN, "On the Establishment of Land Administration Systems in the Eastern European Countries" Guideline of Economic Commission of UN (Geneva), 1996;

14. World Bank Discussion Papers, Cities without Land Markets Alain Bertaud, Bertrand Renaud, 1994;

15. UNCHS, Land, Land Markets and Settlement Planning, 1996;

16. Dowall, David, and Clarke, Giles, A Framework for Reforming Urban Land Policies in Developing Countries, 1991;

17. PADCO, Strategic Plan for Greater Tirana, 2002;

18. Landell Mills, Sustainable \& Integrated Development Tirana-Durres Region, 2007;

19. World Bank, Status of Land Reform and Real Property Markets in Albania, 2006. 